\title{
Historie og kulturel erindring i Det Gamle Testamente
}

\author{
Professor, dr.theol. \\ Niels Peter Lemche
}

\begin{abstract}
It is an established fact that biblical historiography is fundamentally different from modern historical reconstructions. It was never the aim to describe the past as it really was. The purpose of historiography was didactic, and the means had little to do with modern historical reconstructions. In this way it is preferable to consider biblical historiography to be cultural memory, and it is sharing with memory the right not to be dependent on historical facts. Rather it represents a "memory" of the past as constructed by an elite group - the few who were able to write and read. It is possible to reconstruct the "profile" of these intellectuals and their aim: to write a national history, and clearly for propagandistic reasons, to support the primacy of Jerusalem over Samaria. Most likely this historiography dates to the Hasmonean period, although it incorporates many elements of a perhaps much older date.
\end{abstract}

Key words: The Old Testament - ancient history - cultural memory

Når man præsenterer "uindviede" for fænomenet kulturel erindring / kollektiv erindring, mødes man gerne med en vis undren, fordi de ikke kan undgå at få indtrykket af, at hele diskussionen herom er ret diffus. Er kollektiv erindring det samme som kulturel erindring? $\mathrm{Og}$ bevæger vi os videre til definitioner på disse begreber, hvori adskiller f.eks. kulturel erindring sig da fra historie? Erindring har jo i sagens natur noget med fortiden at gøre; men det har historien så sandelig da også. Overlapper historie og kulturel erindring hinanden, eller er det to helt forskellige ting?

\section{Historie og erindring}

Dette sidste vigtige punkt er aktuelt i nutiden, fordi den moderne verden opererer med et historiebegreb, der blev lagt fast i romantikken og som i essensen stadig har som mål at genfortælle, "hvad der 
virkelig skete". Det kan man sige, at erindringen også har som mål; men der stilles ingen videnskabelige krav til erindringen om metoder og procedurer, som skal følges. Erindring er, som den, der husker, nu engang erindrer fortiden, hvormed som regel menes den fortid, som vedkommende selv har kendt til. En, der som denne forfatter i en eller anden funktion var deltager i ungdomsoprøret i 1968, har en personlig erindring om begivenhederne og personerne, der manifesterede sig i oprøret det forår, og vil derfor måske se med en vis undren på historiske rekonstruktioner af, hvad der faktisk skete. ${ }^{2}$ Deltagerne i frihedskampen så langtfra altid med megen forståelse på de historiske rekonstruktioner af frihedskampen, som fulgte, ikke hos den første generation af historikere efter krigen, men derefter, og lod tydeligt deres utilfredshed komme til orde, og kunne, så længe veteranerne var i live, i realiteten bestemme, hvad historikeren måtte skrive. $\mathrm{Nu} \mathrm{er}$ de på nær nogle få borte, og der vil derfor i fremtiden være en anderledes frihed for historikere, der beskæftiger sig med modstandskampen og dens betydning under besættelsen. Forholdet mellem historie og erindring kan på det plan nærmest sammenlignes med vidnets funktion i en retssag: Vidnet kan kaste lys over en sag, men regnes bortset fra $\mathrm{i}$ exceptionelle tilfælde ikke for pålidelig nok til alene at afgøre sagens udfald. Retssagen afgøres på grundlag af en sammenstykning af vidnesbyrd. På samme måde vurderer historikeren en række vidnesbyrd, uanset arten, for at stykke et billede sammen af det emne, som vedkommende ønsker at rekonstruere. Historikeren har til sin rådighed et sæt regler - vi siger også metoder - som han må følge for at blive taget seriøst som historiker. ${ }^{3}$ Den, der erindrer, har derimod ikke et sådan sæt af regler, der regulerer erindringsstrømmen. På den måde kan man faktisk i en nutidig kontekst klart skille erindring fra historie. Kulturel erindring er, når man forstår den som kollektiv

1. Udtrykket stammer fra den tyske historiker Leopold von Ranke (1795-1886), og findes i forordet til hans ungdomsværk Geschichten der romanischen und germanischen Völker von 1494 bis 1535 (Leipzig u. Berlin: G. Reimer 1824). Sml. videre Teddy Brunius, "Wie es eigentlich gewesen': Leopold von Ranke och hans slagord," Scandia 29 (1963), 392-400 (www.scandia.hist.lu.se).

2. Jeg var formand for det teologiske studenterråd ved Københavns Universitet $\mathrm{i}$ 1968 og således tæt på begivenhedernes centrum. Se også min artikel "Da studenterrådet blev voksen", Hvad er imod Studentens Kaar: Festskrift til Det Teologiske Fagråd. Hundredårsjubilaum 1912-2012, red. Emil Bjørn Saggau (København: Det Teologiske Fakultet 2012), 33-36.

3. Det er ikke så lidt af en tilsnigelse at skrive "et sæt af metoder". Der er naturligvis mange måder også i nutiden at drive historie-forskning på, som hver især har sit sæt af metoder. Det er ikke opgaven her at redegøre herfor. 
erindring, det som man husker $\mathrm{i}$ et samfund. Det er genstand for historikernes analyser, men er ikke i sig selv historie. ${ }^{4}$

Men én ting er, hvordan det forholder sig med erindring vis-à-vis historie i nutiden. Noget andet er det, når vi bevæger os tilbage til en tid, hvor det moderne historiebegreb endnu ikke var blevet formuleret - det vil i realiteten sige al historieskrivning fra oldtiden og frem til den nyere tid. Tager man historiens fader, Herodot (5. årh. f.Kr.), så skriver han $\mathrm{i}$ indledningen til sine Historier:

Herodot af Halikarnassos' undersøgelser publiceres herved for at ikke det, som mennesker har gjort gennem tiden, skal blive glemt, for at ikke både grækeres og barbarers store og forunderlige gerninger skal blive ukendte, og desuden for at forklare årsagen til, at de kæmpede mod hinanden.

Det græske ord historie, som her står i flertal og er oversat med "undersøgelser", refererer ikke til videnskabelige studier, men snarere til det, som blandt journalister går under navnet "research". Herodot var ikke videnskabsmand, han var journalist og skrev om berømmelige mænd og deres gerninger. Derfor bringer han Solon af Athen sammen med Lydiens kong Krøsus - det er vist tvivlsomt, at de nogensinde mødtes - og fortæller lystigt om deres møde og fortsætter derefter bl.a. med røverhistorien om Polykrates' ring, som blev fundet i en fisks indre. Han gør store omveje og bruger én af sine otte bøger til at beskrive Egypten, hvor han nok havde været, og inkluderer en længere omtale af sæder og skikke i oldtidens Babylon, som det er mere tvivlsomt, at han skulle have besøgt, før han når frem til sit egentlige emne, krigene mellem grækerne og perserne, som var udkæmpet kort før hans fødsel. Og selv om der nu nok er lidt mere hold i hovedtrækkene af disse krige, som de fortælles, så holder Herodot sig ikke tilbage fra at fortælle en række anekdoter, som fortællingen skrider frem.

Det, der klart adskiller Herodot, og for den sags skyld al ældre historieskrivning, fra moderne historieskrivning, er den manglende kritiske sans. Når Herodot en sjælden gang viser kritisk forståelse for det, som han beretter videre om, er det snarere i den form, man også møder den blandt nutidens journalister. Hans kritik er mere i stil med, at "den tror jeg ikke på", eller "den må du længere ud på landet med", som da hans egyptiske informanter fortæller ham, at Nilen går over sine bredder som følge af, at sneen smelter i Etiopien. Herodot "ved godt", at så langt mod syd er man for nær på solen til, at der kan være sne!

4. Generelt til emnet kulturel erindring og historie Geoffrey Cubitt, History and Memory (Manchester: University Press 2007).

5. Herodotus: II 19-31. Herodot siger på én og samme tid, at denne forklaring er bedre end de andre, han har fået, men samtidigt også, at det er den mest usandsynlige. 
Herodots informanter er lokale mennesker, og det er deres forklaringer og overleveringer, som han medtager i sine "undersøgelser". Man kunne sige, at det er de egyptiske præsters erindring om Nilens opførsel, som han optager og viderebearbejder. På samme måde forholder det sig med hans nok så berømte beskrivelse af kvindeauktionen i Babylon, hvor de giftefærdige piger afsættes på markedet til de højstbydende. Man starter med de smukkeste, og overskuddet for salget af dem går som medgift til de grimmeste, og således bliver der fundet ægtemænd til alle pigerne. ${ }^{6}$ Uanset om Herodot nogensinde har være i Mesopotamien, eller han alene bygger på, hvad folk har bildt ham ind, ${ }^{7}$ så er det en morsom historie og værd at fortælle (og genfortælle). Der er fundet i tusindvis af dokumenter fra Mesopotamien vedrørende ægteskabsforholdene, og der er ingen af dem, der underbygger noget af det, som Herodot her fortæller om.

Oplyste mennesker i oldtiden vidste godt, at Herodots ord ikke altid stod til troende; men man beundrede ham alligevel for den elegante stil og for det moralske indhold i hans historier. Faktisk spillede det sidste en langt større rolle end den historiske nøjagtighed, fordi datidens fortællinger om fortiden nødvendigvis måtte have et didaktisk indhold med henblik på opdragelsen af kommende generationer. ${ }^{8}$ Til gengæld anså man Herodots yngre samtidige, Thukydid, for mere pålidelig; men Thukydid skrev også om begivenheder, hvori han selv havde spillet en rolle, og var desuden en højtstående officer i den atheniensiske flåde under den peloponnesiske krig. Militære rapporter giver ikke megen lejlighed til at brodere på indberetningerne. Thukydids beskrivelse af den deloponnesiske krig er derfor samtidshistorie. Man kunne godt kalde den for en erindring; men der gøres ikke et forsøg på at skildre en fortid, der lå før forfatterens egen tid.

Gammelorientalske beskrivelser af fortiden - herunder også den gammeltestamentlige historieskrivning - har heller ikke meget til fælles med en videnskabelig historieskrivning. I virkeligheden ligner den i hovedtrækkene den græske historieskrivning, og denne lighed er da også i nutidens forskning rykket mere og mere ind mod centrum af forskernes bevidsthed. ${ }^{9}$ Det er ganske tydeligt, at det primære mål for fortællerne af såvel den bibelske som den øvrige nærorientalske

6. Herodot I 196.

7. Sml. til spørgsmålet O.E. Ravns klassiske Herodots Beskrivelse af Babylon (København: Nyt Nordisk Forlag Arnold Busk 1942). Til kvindemarkedet, s. 92. Det er interessant, at Ravn sammenfatter Herodots beskrivelse af Babylon som et "erindringsbillede" (98-101).

8. En udmærket fremstilling af historiens rolle i undervisningen findes i Per Ørsted, Romersk historieskrivning: En analyse af en rakke generelle trak $i$ antikkens opfattelse af historiens vasen og formål (København: Gyldendal 1978).

9. Se videre hertil nedenfor. 
historieskrivning ikke var at fortælle om, hvad der faktisk skete, men at præsentere en beretning om fortiden, som kunne være til glæde for forfatternes samtid.

Det gælder således for den hittitiske historieskrivning, som man ofte tidligere så inddraget i diskussionen om den gammeltestamentlige. De mange traktater, som er fundet, mellem hittitterkongen og hans vasaller, men også mellem den hittitiske konge og Egyptens Farao, indeholder i reglen en historisk sektion, som opregner det tidligere forhold mellem de parter, der nu indgår en traktat. Imidlertid er der tale om nøje arrangerede referater af fortiden, som er sammenstykket med netop den nye politiske forbindelse for øje. Egentlig handler det om at præsentere fortiden i det værste lys og fremhæve de gyldne tider, som skal følge traktatindgåelsen - der er for de fleste traktaters vedkommende tale om vasaltraktater mellem hittitterkongen og syriske og lilleasiatiske fyrster. ${ }^{10}$

Vender vi os til Mesopotamien, findes der ingen tilsvarende forsøg på at sammenstille fortidens begivenheder i en selvstændig fortælling. I hovedsagen drejer det sig i såvel babylonisk som assyrisk litteratur om krøniker, dvs. årstalslister med anførsel af den eller de vigtigste begivenheder i løbet af året, eller det drejer sig om kongelige annaler, der i mere udførlig form redegør for felttogene, idet også annalerne egentlig kun er krøniker med lidt mere udførlige indlæg om de enkelte år. ${ }^{11} \mathrm{Og}$ fortsætter vi søgningen til i sidste ende Egypten, finder vi annalistisk litteratur af næsten samme karakter som den mesopotamiske. Både i tilfældet med Mesopotamien og med Egypten forsøger man at redegøre for nutiden ved at henvise til fortiden, men det er ikke fortiden, som den var, men som man forestillede sig den. Der findes beretninger, som går langt videre end til bare at være annalistiske rapporter. Den berømteste egyptiske tekst er nok Ramses II's beskrivelse af slaget ved Kadesh i 1274 f.Kr., som ledsagede billederne af begivenhederne i den sædvanlige egyptiske stil med Farao som den altdominerende skikkelse i centrum og menige egyptere såvel som de hittitiske fjender som pygmæer omkring Farao. ${ }^{12}$ Der er aldrig tale om en kritisk stillingtagen til det fortalte, om end beskrivelsen af slaget er af en sådan karakter, at moderne historikere føler sig klædt på til at rekonstruere begivenhedsforløbet.

10. Traktaterne er oversat af Gary Beckman, Hittite Diplomatic Texts (2. udg.; Atlanta: Scholars Press 1995).

11. Den vigtigste litteratur findes oversat i A. Kirk Grayson, Assyrian and Babylonian Chronicles (2. udgave; Winona Lake: Eisenbrauns 2000).

12. De egyptiske beretninger om dette slag er behandlet af Alan Gardiner, The Kadesh Inscriptions of Ramesses II (Oxford: Printed for the Griffith Institute at the University Press by Vivian Ridler 1960). 


\section{Historiefortællingen i Det Gamle Testamente}

I min introduktion til gammeltestamentlige studier, Det Gamle Testamente mellem Teologi og Historie, har jeg senest redegjort udførligt for, hvorledes det forholder sig med historiefortællingen i Det Gamle Testamente. ${ }^{13}$ Der er derfor ingen grund til at bruge megen plads på at gentage, hvad allerede er at finde i nævnte værk. Kort fortalt indeholder bogen et opgør med 200 års historieforskning baseret på gammeltestamentlige fortællinger, som alt for let har ladet sig misbruge som kilde til historiske oplysninger, således at man reelt kan klassificere de mange Israelshistorier, der er udkommet, som mere eller mindre kritiske parafraser af den gammeltestamentlige fortælling.

Det er imidlertid bemærkelsesværdigt, i hvilket omfang den gammeltestamentlige fortælling ikke stemmer overens med, hvad man de facto kan sige om Palæstinas historie i oldtiden. Man kan nærmest tale om en systemisk, det vil sige tilsigtet, mangel på overensstemmelse, og det viser sig at være ligegyldigt, uanset om man bevæger sig i fortællingens redegørelse for Israels ældste tider eller beskrivelsen af den eftereksilske tid. Uanset, at der naturligvis hist og her findes oplysninger om begivenheder, som har fundet sted - Sankeribs angreb på Jerusalem i 701 f.Kr. og Nebukadnezars på Jerusalem i 597 f.Kr. er klart begivenheder, hvor oplysningerne i Det Gamle Testamente svarer til informationer fra assyriske og babylonske annaler ${ }^{14}-$ så er helhedsindtrykket, at forfatterne til den bibelske fortælling ikke gør noget forsøg på at skildre begivenhederne, wie es eigentlich gewesen, men har et ganske andet formål med deres fortællinger, idet de benytter sig af en række traditionelle fortællestrategier og fortælletemaer kendt fra den Nære Orient i sin helhed, som i den gammeltestamentlige fortælling er føjet sammen for at give et ganske bestemt indtryk af det bibelske Israels skæbne i gamle dage. ${ }^{15}$

I centrum af den bibelske fortælling om Israels historie befinder Jerusalem sig, og i midten af Jerusalem Salomos tempel. Dramaet om Jerusalem omkranses af motivet om indvandringen og erobringen af Israels land og uddrivelsen af landet. Indvandringen og erobringen af Kana’ans land følger på et langt ophold i udlændigheden i Egypten - ren fiktion i den kontekst, hvori temaet optræder i Det Gamle Testamente. Dette tema når til en foreløbig konklusion med Davids

13. København: ANIS 2008.

14. Sankerib: Jf. Daniel David Luckenbill, The Annals of Sennacherib (1924; genoptryk: Eugene: Wipf \& Stock 2005), col. III:18-33 (s. 30-31). Nebukadnezar, Grayson, Assyrian and Babylonian Chronicles, Chronicle 5:11-13, s. 102.

15. Vedr. historien som en "erindringskompot" Thomas L. Thompson, The Bible in History: How Writers Create a Past (London: Jonathan Cape 1999). 
erobring af Jerusalem, som efter alt at dømme ikke eksisterede på det tidspunkt, man har placeret denne erobring, ca. 1000 f.Kr. ${ }^{16}$ Den foreløbige afslutning kommer med Nebukadnezars to erobringer af Jerusalem i 597 og 587 f.Kr., hvoraf den første er velbevidnet også fra babylonsk side. Byen blev i hvert fald totalt ødelagt i den periode, en ødelæggelse, der også omfattede resten af den judæiske stats territorium. ${ }^{17}$ Efter halvfjerds år (bibelsk tidsregning!) vendte det eksilerede folk hjem fra landflygtigheden og overtog sit gamle land.

Heller ikke det sidste skete. Jerusalem blev ikke genopbygget hverken i slutningen af det 6 . årh. f.Kr. eller i løbet af det 5. eller 4. årh. f.Kr. Meget tyder på, at byen faktisk først begyndte at blive genopbygget i det 2 . årh. f.Kr. på et tidspunkt, hvor den langtfra var det naturlige centrum i landet, ${ }^{18}$ men hvor det egentlige centrum lå i Samaria og i Sikem nord for Jerusalem i det område, som måske engang var det egentlige Israel. ${ }^{19}$ Den bastante pro-jerusalemitiske fortælling om Israels skæbne, som vi læser i Det Gamle Testamente, er måske ikke andet end et stykke propaganda fra den periode, hvor Jerusalem

16. Spørgsmålet om Jerusalems historie i det 10. årh. f.Kr. har i hovedsagen været drøftet mellem israelske arkæologer med hjemsted ved universitetet i Tel Aviv og deres kolleger fra The Hebrew University i Jerusalem. Tel Aviv-arkæologerne er i hovedsagen af den opfattelse, at der enten slet ikke lå en by på stedet i den periode, hvori man plejer at placere David og Salomo, eller også var det en ubetydelig flække med en befolkning, der ikke har talt hundrede voksne mænd. For en almen tilgængelig fremstilling fra Tel Aviv-arkæologernes side, cf. Israel Finkelstein og Neil Asher Silberman, The Bible Unearthed: Archaeology's New Vision of Ancient Israel and the Origin of Its Sacred Texts (New York: The Free Press 2001), modificeret en anelse i sammes David and Solomon: In Search of the Bible's Sacred Kings and the Roots of the Western Tradition (New York: The Free Press 2006), især 267-274.

17. Den i dag mest fremtrædende israelske forsker, der beskæftiger sig med denne problematik, er Oded Lipschits. Se især hans The Fall and Rise of Jerusalem: Judah under Babylonian Rule (Winona Lake: Eisenbrauns 2005).

18. Igen foregår der en heftig debat om dette spørgsmål mellem arkæologerne fra Tel Aviv og fra Jerusalem. Indtil nu er det ikke lykkedes for arkæologerne at finde reelle rester fra den tidlige persiske periode som f.eks. Nehemias' mur. Se senest hertil Israel Finkelstein, "Persian Period Jerusalem and Yehud Rejoinders", i Jon Berquist og Alice Hunt, Focusing Biblical Studies: The Crucial Nature of the Persian and Hellenistic Periods. Essays in Honor of Douglas A. Knight, LHBOTS 544; London: T \& T Clark 2012), 49-62, og Oded Lipschits, "Shedding New Light on the Dark Years of the "Exilic Period": New Studies, Further Elucidation, and Some Questions Regarding the Archaeology of Judah as an "Empty Land", i Brad Kelle, Frank Ritchel Ames, and Jacob L. Wright (udg.), Interpreting Exile (Atlanta: Society of Biblical Literature 2011), 57-90.

19. Se videre: Y. Magen, "The Dating of the First Phase of the Samaritan Temple at Mount Gerizim in Light of Archaeological Evidence", i O. Lipschits, G.N. Knoppers, og R. Albertz, Judah and the Judeans in the Fourth Century B.C.E. (Winona Lake: Eisenbrauns, 2007), 157-211. 
stræbte mod at blive landet politiske og religiøse centrum på bekostning af de tidligere centre nord for Jerusalem.

Den gammeltestamentlige fortælling om Israels skæbne er på denne måde propagandalitteratur, der er sat sammen af politiske grunde og med et politisk sigte, der skal placere Jerusalem med dets tempel som det egentlige centrum i Israels land. Til at samle denne fortælling har forfatterne benyttet en palet af foreliggende motiver af meget forskellig karakter. Indvandrings- og erobringstemaet er velkendt fra antikken, specielt fra den græske tradition, som får sit forstærkede nedslag i den romerske tradition om trojanerhelten Æneas' rejse til Italien efter Trojas fald. ${ }^{20}$ Dommertiden repræsenterer den såkaldte "heroiske tid", som er en del af mange kulturers - for den sags skyld også den danske - erindringer om deres fortid. ${ }^{21}$ Davidsberetningen er sammensat af to fortællinger, dels en lang eposlignende beretning om den unge helt, der går så meget ondt igennem for at vinde prinsessen og det halve kongerige, en fortælling som i høj grad var velkendt i den gamle Orient, ${ }^{22}$ dels historien om et familiedrama, som kun har sin lige i græske dramaer om familier i opløsning. ${ }^{23}$

Men for at gøre en lang historie kort: Der findes ikke i Det Gamle Testamente historieskrivning. Det er en moderne konvention, at det skulle være der og er udtryk for en manglende forståelse for, hvad det er for et fænomen, vi står overfor i Det Gamle Testamente. Vi kunne kalde den gammeltestamentlige fortælling for erindringslitteratur, idet den deler erindringens privilegium ved ikke at behøve at tage hensyn til, hvad der faktisk skete engang for længe siden. Det ville være nærliggende at tale om denne fortælling som kulturel erindring.

\section{Kulturel erindring i Det Gamle Testamente}

Derved er vi nået til hovedspørgsmålet: Hvis vi opfatter den gammeltestamentlige historieskrivning som kulturel erindring, hvis erin-

20. Sml. Virgil, Eneiden, forfattet mellem 29 og 19 f.Kr.

21. Grundlæggende er stadig Hector Munro Chadwick, Heroic Age (Cambridge: University Press 1912).

22. Denne motivmæssige sammenhæng blev først påvist af Giovanni Buccellati, "La 'carriera' di David e quella di Idrimi, re di Alalac", Bibbia e Oriente 4 (1962), 95-99, og analysen udvidet af Mario Liverani, "Partire sul carro, per il deserto", Annali dell'stituto Universitario Orientale di Napoli NS 22 (1972), pp. 403-415, engelsk: "Leaving by Chariot for the Desert", i Liverani, 2004:85-96.

23. Man kan tænke på såvel prosafortællinger som egentlige dramaer som Euripides' Medea, Sofokles' Ødipus, ja, i det hele taget familiedramaet som det bærende tema i det meste af den overleverede dramatiske litteratur lige siden Aiskylos' Orestien. 
dring er der da tale om? Det spørgsmål er faktisk ikke vanskeligt at besvare, med mindre man vil have nøjagtige navne på forfatterne og datoerne for deres virke. Det er i realiteten umuligt at sige, hvem forfatterne var, og hvornår de skrev. Derimod kan man begynde med det, som vi faktisk er i besiddelse af, og lave en "profil" af forfatterne: Hvad skrev de om? Hvorfra havde de deres motiver og fortællinger? Hvad var hensigten med det, de skrev? Hvad var deres position i det samfund, som de tilhørte?

Jeg har tidligere forsøgt mig med en beskrivelse af denne forfatterprofil. ${ }^{24}$ Heraf fremgik det, at forfatterne til de gammeltestamentlige fortællinger var lærde mennesker, med kendskab til ikke bare lokal palæstinensisk (israelitisk) tradition, men til den nærorientalske tradition over en bred kam. De elaborerer på egyptiske fortællinger i snævrere forstand som i beretningen om Josef og Potifars hustru, som er en selvstændig bearbejdelse af den egyptiske fortælling om to brødre, hvis forhold ødelægges af den enes hustru, som forsøger at forføre den anden broder, ${ }^{25}$ men er også orienterede om egyptiske forhold i almindelighed. ${ }^{26}$ På samme måde vandrer de specielt i urhistorien i Genesis 1-11 frit rundt i den babylonske mytologi og præsenterer endda en gennemskrivning af den babylonske syndflodsfortælling, måske tilmed af den udgave, der findes i det i datiden populære Gilgameshepos. ${ }^{27}$ Temaer og motiver, som har deres hjemsted i græsk tradition, er heller ikke ukendte. Det mest kendte udslag heraf er nok beskrivelsen af verdens skabelse i Genesis 1, der i sin prioritering af de fire elementer, det varme (lyset), det kolde (mørket), det våde (vandet), og det tørre (landet) minder ikke så lidt om græsk naturfilosofi. Man har sammenlignet det med den joniske naturfilosofi som f.eks. hos Thales fra Milet. ${ }^{28}$ I det hele taget har man i nutiden fået større og større sans for at se sammenhænge mellem litteraturen i Det Gamle Testamente og den græske tradition, hvilket i sig selv ikke er særlig bemærkelsesværdigt, eftersom der i dag kommer stadig flere forskere

24. "How does One Date an Expression of Mental History? The Old Testament and Hellenism", in L.L. Grabbe (red.), Did Moses Speak Attic? Jewish Historiography and Scripture in the Hellenistic Period, JSOTSS 317 (Sheffield 2001), 200-224.

25. Sml. den egyptiske fortælling om de to brødre, oversat i William W. Hallo, The Context of Scripture, I (Leiden: E. J. Brill 1997), 85-89.

26. Sml. Donald B. Redford, A Study of the Biblical Story of Joseph (Genesis 37-50), VTS 20 (Leiden: E. J. Brill 1970).

27. Jf. Niels Peter Lemche, "Gammeltestamentlige tekster som genskrevet litteratur", i Jesper Høgenhaven og Mogens Müller (red.), Bibelske Genskrivninger, FBE 17 (København: Museum Tusculanum 2012), 51-73.

28. John Van Seters, "The Primeval Histories of Greece and Israel Compared", Zeitschrift für die alttestamentliche Wissenschaft 100 (1988), 1-22, genoptrykt i sammes Changing Perspectives I: Studies in the History, Literature and Religion of Biblical Israel (London: Equinox 2011), 335-358. 
til, der opfatter Det Gamle Testamente, eller rettere litteraturen som er indeholdt i Det Gamle Testamente, for at stamme fra den sene persiske og tidlige hellenistiske tid, dvs. fra det 4. og 3. årh. f.Kr. ${ }^{29}$

Når vi derfor taler om kulturel erindring i Det Gamle Testamente, handler det om en højlærd "erindring" formidlet af mennesker med en betragtelig uddannelse og en bred horisont bag ved sig. Det er ikke en litteratur, som udspringer af de små landsbysamfund i Palæstinas bjergegne, eller for den sags skyld i det førhellenistiske Jerusalem, som næppe var mere end en flække på en øde bjergtop i Judas bjerge. Den israelske arkæolog Israel Finkelstein taler i den forbindelse om en bosættelse på mindre end to hektar i omfang og med en befolkning på måske 500 mennesker, dvs. med mindre end hundrede voksne mænd..$^{30}$ Der har ganske vist siden det 5 . årh. været en helligdom på stedet, med en "ypperstepræst", men der er ingen oplysninger om størrelsen på dette "tempel", ${ }^{31}$ hvis helligstedstradition dog har været stærk nok til, at en brevskriver fra Elefantine skriver til Jerusalem i forbindelse med opførelsen af et nyt Jahvetempel på Elefantineøen i det sydlige Egypten. ${ }^{32}$

Rehabiliteringen af samaritanerne og deres tradition i nutiden og fundet af en betragtelig samaritansk by på Garizim ved siden af det samaritanske tempel vil givetvis føre til en øget forstålse af samaritanernes betydning for den jødiske traditionsdannelse i Det Gamle Testamente, ikke mindst hvis det viser sig at være korrekt, at selveste navnet "Israel", knyttede sig til det samaritanske samfund og først sekundært overførtes på det jødiske samfund i Jerusalem. ${ }^{33}$ Er det

29. Man kan ligefrem tale om en gryende "pan-hellenisme" i stil med fortidens pan-babylonisme, som dominerede dele af den gammeltestamentlige forskning for hundrede år siden. Jeg kan ikke unddrage mig et hovedansvar, da programmet for en forskning, der rettede søgelyset mod Hellas blev formuleret af mig i en forelæsning i Teologisk Forening på Københavns Universitet i 1991, og oprindeligt publiceret som "Det gamle Testamente som en hellenistisk bog", DTT 55 (1992), 81101. Foredraget er siden udkommet i flere engelske oversættelser, senest som "The Old Testament-A Hellenistic Book?" i Niels Peter Lemche, Biblical Studies and the Failure of History: 3: Changing Perspectives, CIS (London: Equinox 2013), 133-157. Som et af de mest markante udslag af denne forskningsretning kan nævnes Philippe Wajdenbaum, Argonauts of the Desert: Structural Analysis of the Hebrew Bible, CIS (London: Equinox 2011).

30. Cf. Finkelstein 2012.

31. Hvis da ikke lige oplysningen (Ezra 3,12-13) om, at jøderne i Jerusalem græd, da de så deres nye tempel, og erindrede det gamle tempels storhed og glans, står til troende.

32. Se til brevet fra Elefantine: A. E. Cowley, Aramaic Papyri of the Fifth Century B.C. (Oxford: The Clarendon Press 1923; genoptrykt Eugene: Wipf \& Stock 2005), nr. 30:18:יהונתן כהנא רבא.

33. Sml. hertil Niels Peter Lemche, "The Greek Israelites and Gerizim”, i Plogbillar \& svärd: En festskrift till Stig Norin, red. Tal Davidovich (Uppsala: Molin \& Sor- 
korrekt, så tegner der sig et broget billede af den kulturelle erindring, som fortællingerne i Det Gamle Testamente repræsenterer. Det næste trin bliver at bestemme, hvad denne erindring er god for. Hvad er forfatternes formål med beretningerne?

Det er ikke usædvanligt blandt erindringsforskere at møde udsagnet, at "historien er et masseuddannelsesvåben", dvs. at historien er en måde, hvormed et samfund skaber sin identitet, således som det reelt skete i Europa i kølvandet på den franske revolution med dens totale opgør med den overleverede tradition, der byggede på sammenhængen mellem herskeren (kongen) og dennes undersåtter. Da kongen "tabte hovedet", manglede staten sit centrum, og et nyt centrum opstod, "folket". For at skabe et folk krævedes samhørighed mellem mennesker, der tidligere måske kun havde det til fælles, at den samme konge regerede over dem. Hovedmidlet blev historien, forstået som en fortælling, der viser "folkets" fælles skæbne gennem tiden. $^{34}$

De gammeltestamentlige fortællinger kan kaldes det israelitiske folks fødselshistorie. Den deler mange træk med den senere europæiske nationale historieskrivning og har tydeligvis til hensigt at berette om, hvorledes det israelitiske folk blev ét. I fordums dage mente man gerne, at oprindelsen til denne historieskrivning skulle søges på Davids og Salomos tid. Den havde netop til hensigt at skabe en sammenhæng mellem de forskellige dele af disse kongers rige. ${ }^{35}$ Man sammenlignede undertiden denne historieskrivnings rolle med den romerske historieskrivning i det tidlige kejserdømme, som producerede en række historieskrivere og digtere, som kunne berette om det romerske folks nationale historie, og som derved skabte det ideologiske fundament for det nye romerske kejserrige. Man tænker i første række på Titus Livius, hvis kun delvis bevarede romerske historie fyldte 142 bøger, og på Virgil, hvis Æneide beretter om Roms ældste tider, men som slutter med foreningen efter en række krige mellem romerne og deres naboer. ${ }^{36}$

genfrei 2012), 147-154. Grundlaget herfor er to votivindskrifter fra omkring 200 f.Kr. sat op på Delos af mennesker, som kaldte sig for israelitter og stammede fra Kreta, med henvisning til deres troskab mod templet på Garizim.

34. Mere herom i Niels Peter Lemche, Det Gamle Testamente mellem teologi og historie: Den historisk-kritiske bibelforsknings storhed og fald (København: ANIS 2008), $312 \mathrm{ff}$.

35. Sml. hertil Gerhard von Rad, "Der Anfang der Geschichtsschreibung im alten Israel”, (1944), optrykt i sammes Gesammelte Studien zum Alten Testament (Theologische Bücherei; München: Chr. Kaiser, 1958), 148-188.

36. Livius' historie, $A b$ urbe condita libri, ca. $27-25$ f.Kr. Heraf er ca. 35 bøger bevaret. Vedrørende Virgils Æneide jf. n. 20 ovenfor. 
I en gammeltestamentlig sammenhæng, hvor historieskrivningens forankring på Davids og Salomos tid er umuliggjort af det samlede israelitiske riges forsvinden fra den historiske debat, har man været nødsaget til at tænke i andre baner; det er derfor blevet relevant at se på udviklingen, der i slutningen af det 2. årh. f.Kr. førte til en "samling" (der var nok mere tale om erobring) af den centrale del af Palæstina i form af hasmonæernes rige. ${ }^{37}$ Man behøver dog ikke nødvendigvis at tænke litteraturen helt så sen. Der er måske nok så megen grund til at anse den for at være propaganda etableret med henblik på skabelsen af en "israelitisk" — i realiteten en judæisk stat, som frit har lånt fra den samaritanske tradition; men som også har tilsidesat den ved at gøre Jerusalem til centrum i overleveringen om det bibelske Israel. Eller man kan sige, at mens centrum i Israel engang var Sikem, hvor samaritanernes tempel lå, flyttedes centrum nu til Jerusalem, mens det samaritanske tempel ødelagdes, og samaritanerne selv i fremtiden blev opfattet som et pariafolk. ${ }^{38}$

At tidsansætte den udgave, vi har af fortællingen om det israelitiske folk, til det 2. årh. f.Kr., betyder samtidig, at vi placerer den i en sammenhæng, der giver plads til forskellige kulturstrømme, der i den forenes til en sammenhængende beretning. Ganske vist havde hasmonæerne deres åndelige baggrund i modstanden mod helleniseringen af den centrale del af Palæstina, der først tog fart efter 200 f.Kr. ${ }^{39}$ Men det har ikke forhindret hellenismen i alligevel at komme ind ad bagdøren, meget på samme måde som man i nutiden ser Mellemøsten reagere voldsomt på den vestlige politiske og især kulturelle indflydelse: Men uanset dette er man i kulturel henseende fuldstændig i vesterlandets vold.

Hvordan formidlede man i den hasmonæiske tid fortællingen om det israelitiske folk, hvis centrum skulle være Jerusalem, til almindelige mennesker i det nyetablerede hasmonæiske rige? Det Gamle Testamente giver faktisk en række informationer herom. Centrum i riget er templet i Jerusalem, hvor Israels Gud har valgt at bo. Til templet kommer man, når man vil dyrke sin Gud. Det kunne ske i den daglige kult, men især spillede valfartsfesterne her en central rol-

37. Hvis vi taler om det 2. årh. f.Kr. taler vi også om Johannes Hyrkan (134-104 f.Kr.). Mange vil dog foretrække at henvise til Josias's tid (639-609 f.Kr.), som dog har det handikap, at vi ikke kender noget til den tid undtagen fra Det Gamle Testamente.

38. Templet på Garizim ødelagdes af Hyrkan.

39. Til helleniseringen af Palæstina, Hans-Peter Kuhnen, "Israel unmittelbar vor und nach Alexander dem Großen: Geschichtlicher Wandel und archäologischer Befund", Die Griechen und das antike Israel: Interdisziplinäre Studien zur Religionsund Kulturgeschichte des Heiligen Landes, red. Stefan Alkier og Markus Witte, OBO 201 (Freiburg: Presse universitaire, 2004). 
le, påsken, pinsen, og løvhyttefesten (Leviticus 23). Alle disse fester havde deres baggrund i det palæstinensiske agrarsamfund, påsken var knytter til byghøsten, pinsen til hvedehøsten og løvhyttefesten til frugthøsten, men som det for længst er blevet fremhævet, så var disse fester langt mere en høstfester, fordi de alle var inkorporerede i den historiske fortælling, og således alle blev til "erindringssteder" for den jødiske, dvs. den israelitiske bevidsthed om folkets fortid. Johannes Pedersen inkluderede for mange år siden i sin Israel et ekskurs om påskefortællingen som en festlegende og en erindringsfortælling. ${ }^{40} \mathrm{Han}$ havde givetvis ret.

Ved festerne doceredes de vigtigste dele af historiefortællingen til de fremmødte i templet, i princippet hele folket. Men dette var ikke nok. Et skrift i Det Gamle Testamente går langt videre end til blot at anbefale deltagelsen i de centrale højtider i Jerusalems tempel. Det lægger mindst lige så stor vægt på overleveringen inden for familien, som det fremgår af Deuteronomium, hvori svarene præsenteres til sønnen, der spørger om loven (Deut 6,20-25), der indeholder hele Israels tidlige historie i en kortform, som et credo. I det hele taget er Femte Mosebog en formaningstale om at huske Jahves handlen med Israel i historien og ikke at glemme, hvad Jahve har gjort for Israel. Kerneordene er på hebraisk שכתח "at huske" og "at glemme". Man kan uden at overdrive præsentere Deuteronomium som et propagandaskrift og som det klareste eksempel på historien brugt som masseinstruktionsvåben, som overhovedet er overleveret fra oldtiden.

\section{Opsummering}

Den lange fortælling om Israels skæbne i Det Gamle Testamente er et stykke kulturel erindring, der som al erindring ikke først og fremmest har fortiden som sin genstand, men fortiden således som nutiden (dvs. forfatternes samtid) forestillede sig den. Denne fortælling består af mange enkelterindringer. F.eks. er Sikems rolle i traditionerne bemærkelsesværdig både i positiv og negativ henseende. Eduard Nielsen demonstrerede for snart tres år siden i sin disputats om Sikem, hvorledes Jerusalemvenlige og Sikemvenlige traditioner brydes, ikke blot i Mosebøgerne, men også i de efterfølgende historiske bøger..$^{41}$ I Sikem svejses det israelitiske folk sammen gennem pagten med Jahve (Josva

40. Johannes Pedersen, Israel, III-IV: Hellighed og Gudommelighed (2. udg.; København: Branner og Korch 1960), 549-555, ekskurs 1: "Overgangen over Sivhavet og Paaskelegenden".

41. Eduard Nielsen, Shechem: A Traditio-Historical Investigation (Copenhagen: G.

E. C. Gad 1955). Med henblik på en vurdering af dette værks placering inden for 
24), og i Sikem opløses folket igen i på den ene side Israel og på den anden Juda (1 Kong 12). Andre, såvel israelitiske som judæiske erindringer, blander sig i denne kulturelle erindringsfortælling.

Én ting er sikker: Det er ikke erindringen hos folk som flest, som kommer til udtryk i Det Gamle Testamentes kulturelle erindring. Det er erindringen, som den blev lagt fast af en intellektuel elite bestående af nogle få procent af befolkningen, nemlig af de få, som kunne læse og skrive. Hvad den almindelige befolkning har gået og husket på, det er tabt, ikke mindst fordi der er så uendeligt lidt materielt fra det gamle Palæstina, der er bevaret, og som f.eks. i form af billedkunst kunne give en antydning af, hvad man gik og tænkte på. Selv keramikken, som der er nok af, er nærmest anonym og røber ingen intellektuelle aktiviteter, som man kunne knytte til en levende erindring. Figurkunsten er så primitiv, at jeg undertiden nærmest i spøg har hævdet, at billedforbuddet skyldtes den jammerlige evne til at udtrykke sig i billeder.

den nyeste forskning, jf. Niels Peter Lemche, "When the Past Becomes the Present", Scandinavian Journal of the Old Testament 27 (2013), 99-109. 